Fourth International Conference on Sustainable Construction Materials and Technologies http://www.claisse.info/Proceedings.htm

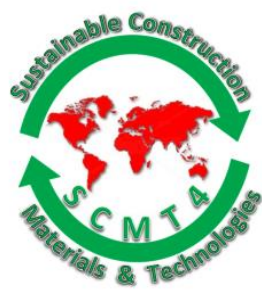

SCMT4

Las Vegas, USA, August7-11, 2016

\title{
An Overview of an Electric Utility's Combustion Products Utilization Program
}

\author{
Bruce W. Ramme ${ }^{1 \mathrm{a}}$, Robert Meidl ${ }^{1 \mathrm{~b}}$, Robert Paulson ${ }^{1 \mathrm{c}}$, and Liz Stueck-Mullane ${ }^{1 \mathrm{~d}}$
}

${ }^{1}$ We Energies, 333 W. Everett Street, Milwaukee, WI 53203, USA, ${ }^{1 a}$ Email: <bruce.ramme@weenergies.com>, ${ }^{1 b}$ Email: 〈bob.meidl@we-energies.com>, ${ }^{1 c}$ Email: 〈robert.paulson@we-energies.com>, ${ }^{1 d}$ Email: <liz.stueck-mullane@we-energies>.

\begin{abstract}
This paper presents an overview of applied combustion products research progress at We Energies, an electric, gas and steam utility headquartered in Milwaukee, Wisconsin, USA on the utilization of fly ash, bottom ash, gypsum and wood ash for use in agriculture and construction. Environmental sustainability benefits are highlighted and include conservation of energy and natural resources as well as reducing $\mathrm{CO}_{2}$ and other environmental impacts. Economic and social benefits include development of construction technologies for longer life structures with reduced costs, the opportunity for shorter construction schedules, and reduced impacts for facility users.
\end{abstract}

In 1980, utilization of We Energies coal combustion products stood at five percent. Landfill design standards and costs increased substantially since that time, and landfill facilities have also become more difficult to site. Significant research was conducted to identify and evaluate uses for combustion products to the point where full utilization has been achieved. Beneficiation technologies were also developed and sometimes patented for transformation of materials that were not being utilized into sought-after materials for construction and manufacturing.

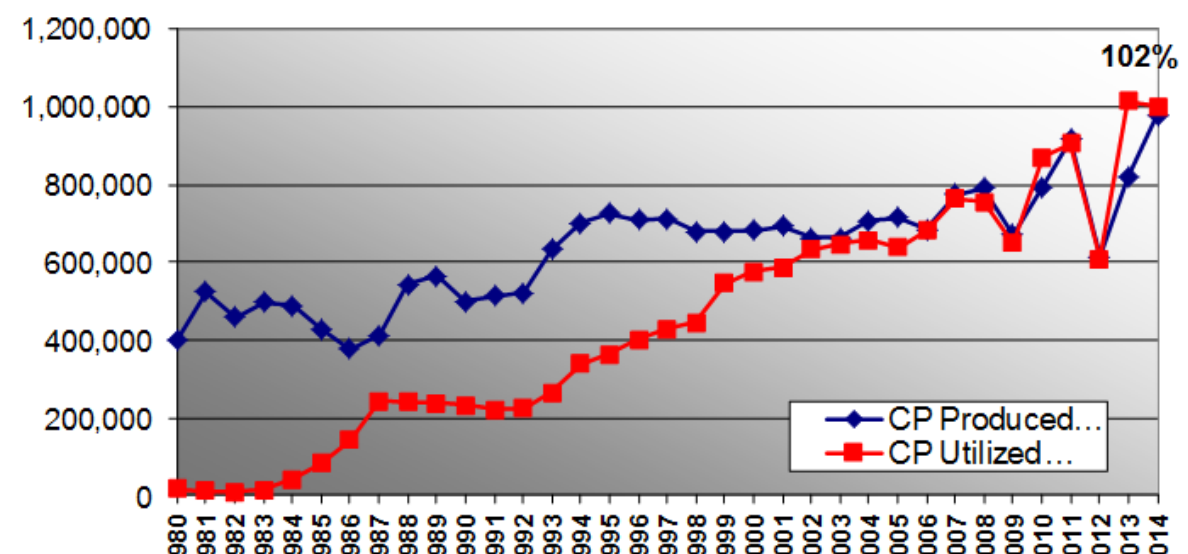

Figure 1. Combustion Products Utilization 1980 - 2014

We Energies, Milwaukee, Wisconsin, U.S.A. 


\section{INTRODUCTION}

Combustion of coal in the United States generates approximately 118 million metric tons (130 million tons) of coal combustion products annually in the form of fly ash, bottom ash, slag, and flue gas desulfurization materials. With the widespread installation of electrostatic precipitators in the early 1970's, utilization of coal combustion products in the United States has gradually grown to over 56 million metric tons (62 million tons) (48\%) in 2014 [American Coal Ash Association 2015]. Significant quantities remain to be utilized and as coal combustion product landfilling and disposal costs increase, beneficial use options may become more cost effective for many utilities

Utilization of We Energies coal combustion products has grown from about five percent in 1980 (Figure 1) to nearly $102 \%$ in 2014 [Meidl, 2015] during which time production quantities of combustion products more than doubled. In addition to materials produced from the combustion of coal, over 36,000 metric tons (40,000 tons) of wood ash from biomass based generation were also produced and beneficially utilized. Since 1980, a significant amount of research has been conducted to identify and evaluate uses for We Energies combustion products materials. Throughout that time, regulations and disposal costs have escalated substantially. This increase was largely attributable to significant changes in landfill design regulations, and the increasing difficulty of siting new landfills.

\section{PROPERTIES OF COAL COMBUSTION PRODUCTS}

Examples of the chemical and physical composition of We Energies Class $\mathrm{C}$ fly ash from its various coal fueled power plants are shown on Tables 1 and 2 respectively. Both Class $\mathrm{C}$ and $\mathrm{F}$ ashes are pozzolanic, but the Class $\mathrm{C}$ fly ash is also cementitious due to the high concentration of calcium oxide.

Four important characteristics of fly ash that affect its usage potential include loss-on-ignition, foam index, residual ammonia content, and consistency of product performance. Low residual ammonia content, losson-ignition values, and consistency are very important considerations in ready-mix concrete utilization because of the need in many applications to control ammonia odor, the quantity of entrained air, and to maintain consistent color. These criteria are not as critical in many other types of fly ash utilization such as use for a raw material in the manufacture of cement, in soil stabilization and use as an ingredient in asphalt, or the cold in-place recycling use in full depth reclamation of asphalt pavements.

The utilization potential of bottom ash is mainly determined by physical characteristics such as grain size distribution, soundness, staining potential and color. The normally coarse, fused, glassy texture of bottom ash makes it an ideal substitute for natural aggregates. However, the presence of iron pyrites in sufficient quantities $(>3 \%)$ can cause staining in some applications such as use as an aggregate in concrete masonry units. In applications where staining is a concern, measures should be taken to keep iron pyrites and other coal mill reject materials separate from the bottom ash. Bottom ash screening may be required for aggregate applications where a specific grain size distribution is required.

\section{UTILIZATION OF ASTM C-618 CLASS C AND F FLY ASH}

We Energies most successful type of utilization of coal combustion products has been the use of Class C fly ash as a cementitious material in Portland cement concrete [Naik and Ramme 1987] [Collins, 1985] [Naik and Ramme 1990]. Extensive research on the effects of Class C fly ash in concrete has demonstrated that variable amounts of portland cement (normally the most expensive component in concrete) can optimally be used with fly ash, thereby reducing the cost of the concrete while enhancing concrete quality. The judicious use of Class $\mathrm{C}$ fly ash in concrete can provide the following advantages over concrete with no fly ash: 
- Increased strength

- Reduced permeability

- Reduced shrinkage

- Increased abrasion resistance

- Reduced bleeding
- Less water demand

- Lower concrete cost

- Improved workability

- Improved pumpability

- Improved durability

Table 1. Chemical Composition of We Energies Fly Ash

\begin{tabular}{|c|c|c|c|c|c|c|}
\hline Source & $\begin{array}{c}\text { ASTM C618 } \\
\text { Class F } \quad \text { Class C }\end{array}$ & $\begin{array}{c}\text { OCPP } \\
\text { Units } \\
5-6 \\
\end{array}$ & $\begin{array}{c}\text { OCPP } \\
\text { Units } \\
7-8 \\
\end{array}$ & PIPP & PPPP & ERGS* \\
\hline $\mathrm{SiO}_{2}, \%$ & - & 36.91 & 36.53 & 37.85 & 39.05 & 38.86 \\
\hline $\mathrm{Al}_{2} \mathrm{O}_{2}, \%$ & - & 19.24 & 19.73 & 18.94 & 20.54 & 19.82 \\
\hline $\mathrm{Fe}_{2} \mathrm{O}_{3}, \%$ & - & 6.09 & 5.80 & 5.50 & 5.47 & 10.17 \\
\hline $\begin{array}{l}\mathrm{SiO}_{2}+\mathrm{Al}_{2} \mathrm{O}_{3}+\mathrm{Fe}_{2} \\
\mathrm{O}_{3}, \%\end{array}$ & $\begin{array}{c}70.0 \mathrm{Min} \\
\text { Min }\end{array}$ & 62.2 & 62.1 & 62.3 & 65.1 & 68.9 \\
\hline $\mathrm{SO}_{3}, \%$ & $\begin{array}{ll}5.0 \operatorname{Max}_{\operatorname{Max}} & 5.0\end{array}$ & 1.47 & 1.24 & 2.14 & 1.56 & 2.50 \\
\hline $\mathrm{CaO}, \%$ & - & 23.55 & 24.08 & 20.39 & 23.14 & 17.91 \\
\hline $\begin{array}{l}\text { Moisture } \\
\text { Content, \% }\end{array}$ & $\begin{array}{cc}3.0 \operatorname{Max}_{\operatorname{Max}} & 3.0 \\
& \end{array}$ & 0.10 & 0.11 & 0.09 & 0.09 & 0.13 \\
\hline LOI, \% & $\underset{\operatorname{Max}}{6.0 \operatorname{Max}^{*} \quad 6.0}$ & 0.49 & 0.32 & 0.84 & 0.25 & 0.39 \\
\hline $\begin{array}{l}\text { Available Alkali } \\
\text { as } \mathrm{Na}_{2} \mathrm{O}, \%\end{array}$ & & 2.1 & 2.1 & 4.8 & 1.7 & 2.1 \\
\hline
\end{tabular}

* Note: ERGS can produce either Class C or Class F fly ash depending on the fuel blend of bituminous or sub-bituminous coals being used.

The most significant of these advantages are increased strength and lower permeability. Strength increases are dependent upon the specific concrete mixture proportions and the proper combination with Portland cement. As illustrated in Figure 2, concrete strength increases with increasing percentages of Pleasant Prairie Class C fly ash, with optimum performance occurring at the 40 percent replacement level. However, all of the fly ash mixtures were stronger at the 28-day age than the control mixture produced without fly ash.

Another use for Class C fly ash is the partial replacement of Portland cement in precast and prestressed concrete units [Naik, Sohns, Ramme 1991]. Research was conducted to determine if high early strength concrete could be produced with high replacement levels of fly ash for Portland cement. The research also evaluated the effects of fly ash content on water demand and workability. The results of this research indicated that:

- Cement replacement with high quality Class C fly ash at levels of up to 30 percent increases early age strength compared to concrete made without fly ash. 
- Fly ash use improves the workability of the mix and thus decreases the amount of water required.

- For the same workability, the water to cementitious material (fly ash and cement) ratio decreased significantly as the fly ash replacement value increased from zero to 30 percent.

Table 2. Fly Ash Physical Properties

\begin{tabular}{|l|c|c|c|c|c|c|c|}
\hline \multicolumn{1}{|c|}{ SOURCE } & \multicolumn{2}{c|}{ ASTM C618 } \\
Class F & \multicolumn{2}{c|}{ Class C } & $\begin{array}{c}\text { OCPP } \\
\text { Units } \\
\mathbf{5 - 6}\end{array}$ & $\begin{array}{c}\text { OCPP } \\
\text { Units } \\
\mathbf{7 - 8}\end{array}$ & PIPP & PPPP & ERGS \\
\hline Fineness: & & & & & & & \\
\hline $\begin{array}{l}\text { Retained on } \\
\text { \#325 Sieve, (\%) }\end{array}$ & 34 Max & 34 Max & 13.9 & 12.4 & 37.85 & 14.9 & 12.2 \\
\hline $\begin{array}{l}\text { Strength Activity } \\
\text { Index with Portland } \\
\text { Cement, (\%): }\end{array}$ & 75 Min & 75 Min & 93 & 98 & 104 & 97 & 112 \\
\hline $\begin{array}{l}\text { \% of Control @ } \\
\text { days }\end{array}$ & 75 Min & 75 Min & - & - & - & - & - \\
\hline $\begin{array}{l}\text { \% of Control @ } \\
\text { 28 days }\end{array}$ & 105 Max & 105 Max & 95 & 95 & 94 & 93 & 94 \\
\hline $\begin{array}{l}\text { Water Requirement: } \\
\text { \% of Control }\end{array}$ & & & & & & & \\
\hline Soundness: & 0.8 Max & 0.8 max & 0.03 & 0.01 & 0.03 & 0.05 & 0.00 \\
\hline $\begin{array}{l}\text { Autoclave } \\
\text { Expansion (\%) }\end{array}$ & - & - & 2.68 & 2.68 & 2.67 & 2.69 & 2.67 \\
\hline Specific Gravity & & & & & \\
\hline
\end{tabular}

The application-oriented research led to the commercial use of Class $\mathrm{C}$ fly ash in locally produced precast and prestressed concrete products.

Self cementing Class C fly ash has also been utilized for the full depth in-place reclamation of asphalt pavements, and for the stabilization of difficult soils for use as a sub-base and base material for pavements, parking lots and building slabs on grade [Crovetti 1998] [Wen et al. 2004] [Wen,Tharaniyil, Ramme 2003].

We Energies can produce either a concrete quality Class C or Class F fly ash at its Elm Road Generating Station depending on the fuel blend of bituminous and sub-bituminous coal being utilized.

A unique blending and processing method of thickening and stabilizing wastewater sludge with fly ash was developed by the North Shore Sanitary District (NSSD) and the American Fly Ash Company [Byers]. NSSD operated a commercial scale processing facility operated from 1986 to 2005 and used both We Energies Class C and Class F fly ash to beneficially stabilize and treat wastewater bio solids. Prior to the start-up of this facility, NSSD wastewater sludge was placed in trenches and left open to evaporate excess water. Combining the bio solids with fly ash thickened the bio solids more rapidly, allowing it to be placed in layers, thereby consuming less land area. The fly ash also served to physically stabilize the bio solids through a pozzolanic reaction between the fly ash and the lime previously added to the sludge in the wastewater treatment process. 


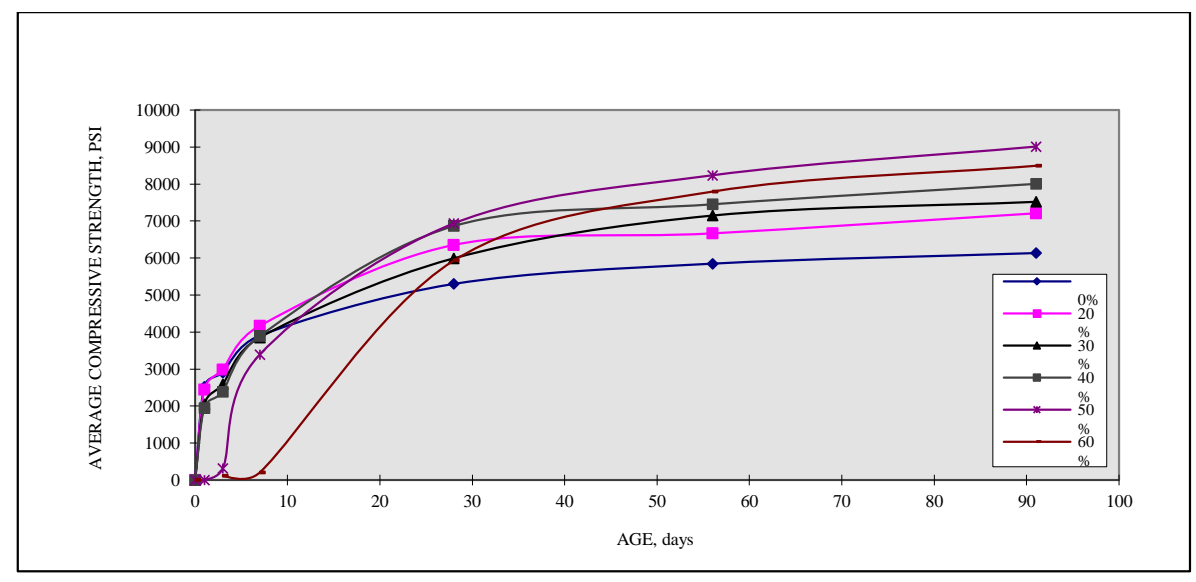

Figure 2. Compressive Strength vs. Age Comparison, 35 Mpa (5000 psi) - 28 Days

Another application for We Energies Class F fly ash is in Controlled Low-Strength Material (CLSM) also known as flowable fly ash slurry [Naik, Ramme, Kolbeck 1990] [Naik, Ramme, Kolbeck 1991] [Naik, Ramme 1994] [Ramme, Naik, Kolbeck 1995]. Flowable fly ash slurry is a mixture of Class F fly ash, cement and water (and sometimes sand) that has excellent flowability during placement. The mixture sets and develops an ultimate compressive strength in the range of $0.345-8.275 \mathrm{MPa}$ (50 to $1200 \mathrm{psi}$ ). The slurry is normally used in non-structural applications below grade where low strength (less than $2 \mathrm{MPa}(300 \mathrm{psi})$ ) is desired to allow for future excavation if necessary. Typical uses include backfill for utility trenches containing ducts, pipes, and manholes, hollow sidewalks, tunnels, underground mine stabilization and as a sub-base for footings, foundations and concrete slabs. The controlled density slurry readily flows to fill voids, and the filled area does not require compaction to avoid settlement. This feature of flowable fill constitutes a major safety, labor and time-saving advantage over conventional fills.

Numerous We Energies projects have utilized flowable fill, including:

- Filling over $518 \mathrm{~m}(1700 \mathrm{ft})$ of electric distribution tunnels under Interstate I-94 Zoo Interchange

- Filling abandoned underground steam heating service tunnels and pipelines in downtown Milwaukee.

- Filling hollow spaces below sidewalks in downtown Milwaukee.

- Backfilling various utility trenches.

- Filling underground storage tanks that are abandoned in place.

- Structural fill to replace over-excavation of poor quality soils.

A potential growth application for Class $\mathrm{C}$ and $\mathrm{F}$ fly ash use is in the production of high-volume fly ash concrete. Laboratory tests performed at the Center for By-Products Utilization at the University of Wisconsin in Milwaukee demonstrated that it was possible to produce high quality concrete with both We Energies Class $\mathrm{C}$ and $\mathrm{F}$ fly ash in quantities of up to $60 \%$ of the cementitious material [Sivasundaram, Carette, Malhotra, 1989; Naik, Sivasundaram, Singh, 1991; Naik, Ramme, Tews, 1994; Tews, 1995] when placed at a low slump and used with a compatible water reducer. Pavements with $40 \%, 50 \%$ and $60 \%$ Class F fly ash cementitious contents compared to the total cementitious content were cast in demonstration sections in the fall of 1990 and 1991 at Pleasant Prairie Power Plant and continue to perform well.

We Energies fly ash has been incorporated as an ingredient in the production of hot-mix asphalt concrete pavements. The benefits of fly ash use in hot-mix asphalt include: improved workability, easier 
compaction to target specified density, improved binder aging resistance, delays age related cracking, extender of asphalt binder or allows reduced binder content, a reduction in binder related issues, thermal stress relief, and reduced potential for thermal cracking [Bautista, Flickinger, Saha, Flores-Vivian, Faheem, Sobolev, 2015; Covi, 2013].

We Energies has investigated and pursued several other successful beneficial use applications to diversify and maximize utilization including:

- An open graded (free draining) base course for pavements with a 28-day compressive strength of 4.8 MPa (700 psi) [Naik, Ramme 1997] was also produced with coarse aggregate, portland cement, and Class F fly ash that worked well.

- Substiwood Incorporated (http://www.substiwood.com) has utilized We Energies Class C and Class F fly ash along with cement and polypropylene fibers to produce a synthetic lumber and other building materials that can be handled in construction like conventional timber materials for a wide variety of applications.

- Class F fly ash from has been utilized by local foundries as a flowability agent for the production of core molds.

- As a raw feed ingredient in manufacturer of portland cement.

These applications among others have resulted in full utilization of We Energies Class C and Class F fly ash. We Energies fly ash, with a long-standing reputation for consistency and quality, is sometimes shipped long distances for special durability and manufacturing applications.

\section{BOTTOM ASH}

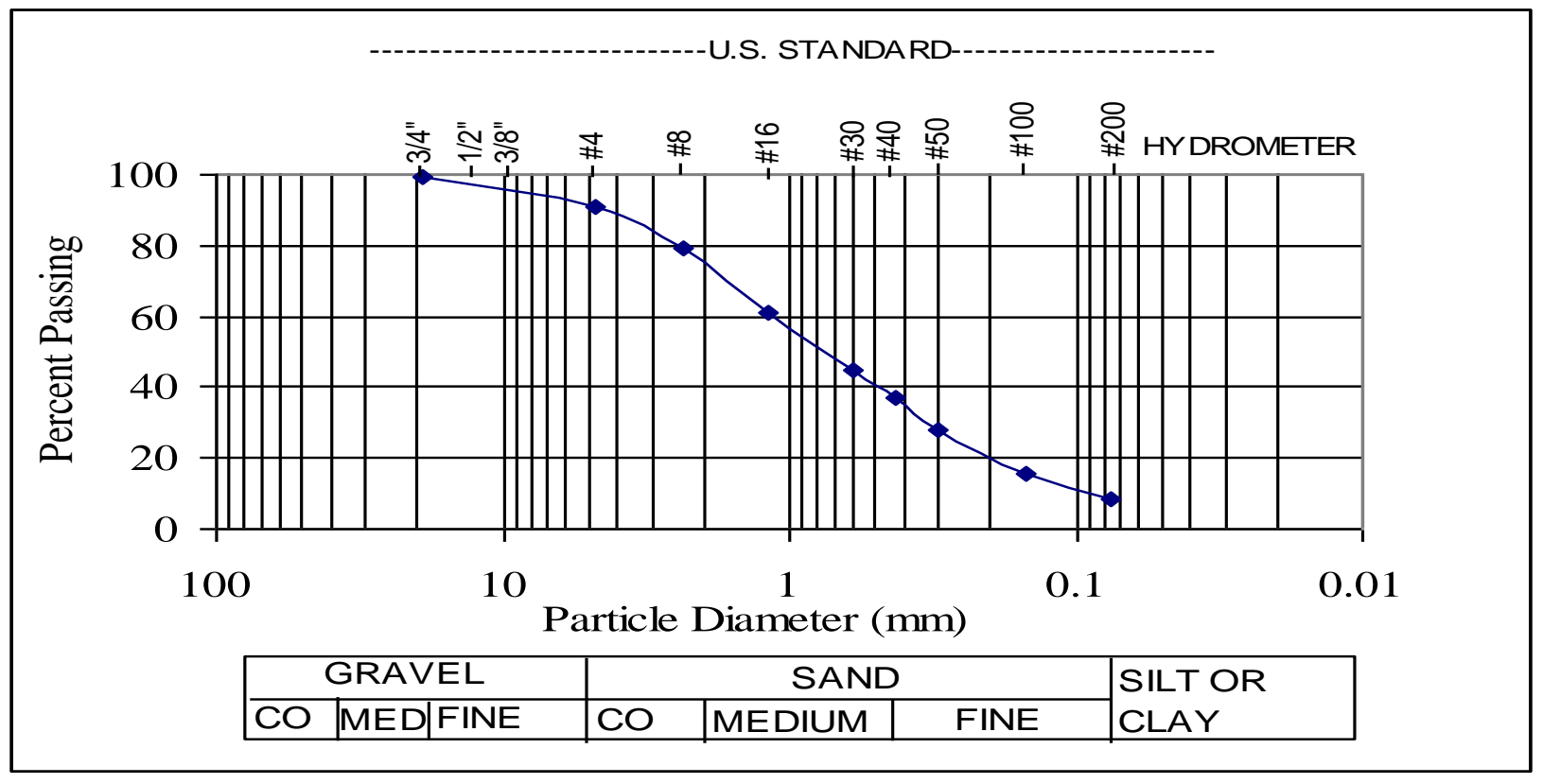

Figure 3. PPPP Bottom Ash Grain Size Distribution Curve

Bottom ash from We Energies power plants has been successfully utilized for many years as a surface course material on service roads, park trails, driveways and "cinder" running tracks, in addition to many on-site plant uses. The use of bottom ash as a sub-base or base material for pavements and foundations has 
been a growth area that reached full utilization of the bottom ash produced at the company's Wisconsin based power plants. Figure 3 shows a typical grain size distribution curve for bottom ash from the Pleasant Prairie Power Plant [Ramme, Kohl, Oakes 1999].

Maintaining a bottom ash inventory at each source is essential to achieving full utilization. The inventory stockpile ensures having adequate quantities on hand to support larger projects but can also serve to blend material from multiple units or plants for gradation consistency and reaching moisture content equilibrium.

In past years, We Energies bottom ash was also used as a soil additive to improve the porosity of clay and organic soils with success [Peterson, Schulte, Speth 1989] and mechanically screened for use in precast masonry units.

Run of stockpile material has been utilized as select structural fill for retaining wall and embankment construction where the lower density, and resulting reduced lateral loads are an advantage. We Energies bottom ash is currently used as a raw feed ingredient in the manufacture of portland cement.

\section{ASH FUEL REBURN AND ASH RECOVERY PROCESSES}

We Energies developed two coal ash beneficiation processes that involve reburning high carbon ash with coal. The processes convert variable carbon content ash into a marketable and useable product while extracting any remaining residual energy content. Ash fuel reburn processes offer several environmental and economic benefits and have been demonstrated at We Energies coal-fired power plants located in Wisconsin and Michigan's Upper Peninsula [Ramme 2003] [Ramme 1999].

We Energies has patented processes (U.S. Patent 5,992,336 and Canadian Patent 2,275,568) that allow bottom ash and fly ash with high loss on ignition (LOI) to be reburned in a pulverized coal furnace. There are two mechanisms that are included in these patented processes - dry and wet (conditioned) ash reburn systems. In the dry reburn system, fly ash is introduced into the boiler with the pulverized coal stream and fed to the burners through an injection port after the classifiers. Alternatively, dry fly ash reburn can be accomplished by injection into the pulverized coal stream before the classifiers; or the secondary air stream entering the furnace adjacent to the coal diffusers of each burner; or through independent injection ports located above or adjacent to the coal stream burners. The wet or conditioned ash reburn system adds relatively coarse bottom ash (or mixtures of bottom ash and wet fly ash) to the coal upstream of the pulverizers. The ash is fed to the unit in direct proportion to the pulverized coal. The materials that are planned to be reburned are periodically analyzed for sulfur, moisture, trace metal and energy content for air emissions and energy analyses.

As shown on table 3, We Energies found it advantageous to reburn variable carbon coal ash from a boiler with less efficient combustion by transporting it to another boiler where more complete combustion occurs. Some utility boilers produce a high LOI ash due to the modified operating conditions required to reduce air emissions of nitrogen oxides $\left(\mathrm{NO}_{\mathrm{x}}\right)$. The high LOI ash (exceeding $20 \%$ LOI) entering the reburn systems is burned to produce a high quality ash with an LOI of less than $1 \%$. The fuel value of the high LOI ash varies with the carbon and moisture content. Generally the fuel value of the ash used at the reburn system, on a dry basis, has been between $3490-11600 \mathrm{~kJ} / \mathrm{kg}(1,500$ and 5,000 Btu/lb).

In addition to high carbon ash being produced by power plants, there are significant volumes of ash historically deposited in existing mono-fill landfills. We Energies developed and patented a process that involves identifying a disposal site that has the appropriate coal combustion product $(\mathrm{CCP})$, recovering at least a portion of the $\mathrm{CCP}$, determining its make-up, and introducing the CCP to a pulverized coal furnace for reburning in the same manner as the conditioned reburn system described earlier. In 2003 We Energies was issued a patent for this ash recovery process (U.S. Patent 6,637,354 and Canadian Patent 2,374,906). 
Both the conditioned and dry reburn processes convert ash that has limited uses and markets into a consistent fly ash and bottom ash that can be used in construction materials. Prior to the ash fuel reburn program, most of the high carbon ash was landfilled. Deployment of these processes was instrumental to transforming ash into useful construction materials and attaining full utilization of We Energies coal combustion products.

Beneficial use of CCP, including materials recovered from the landfills, was facilitated by Wisconsin's beneficial use regulations (Ch. NR538 Wis. Admin. Code) developed during the 1990's. (http://www.legis.state.wi.us/rsb/code/nr/nr538.pdf) These regulations promote pollution prevention and waste minimization by encouraging a broad range of beneficial uses of industrial byproducts while assuring that all appropriate environmental precautions are taken. Use as an alternate fuel is included among the approved beneficial uses. Annual reports are submitted to the WDNR outlining the volumes and characteristics of beneficially used materials.

The ultimate success of the beneficial use program required addressing several challenges related to the ash uses and markets. We Energies is fortunate to have longstanding relationships with innovative ash marketers. The ash marketing contracts were negotiated to allow ash fuel reburn but required that high quality standards must still be met. Quality data collected to date show no negative impact of reburn on the fly ash quality. There are indications that there are positive impacts of the reburn systems on fly ash performance in concrete, but additional studies are needed to substantiate the improvements such as better mitigation of alkali silica reactions in concrete [Ramme, Goeckner 2003] [Malisch 1998] [Naik, Singh, Ramme 1997].

Table 3. Ash Fuel Reburn Results (2000 - 2015)

\begin{tabular}{|c|c|c|c|c|r|}
\hline Plant & $\begin{array}{c}\text { Tons of Ash } \\
\text { Reburned } \\
\text { (metric tons) }\end{array}$ & $\begin{array}{c}\text { Tons of Fly } \\
\text { Ash Produced } \\
\text { (metric tons) }\end{array}$ & $\begin{array}{c}\text { Tons of Potential } \\
\mathrm{CO}_{2} \text { Avoided } \\
\text { (metric tons) }\end{array}$ & $\begin{array}{c}\text { Tons of Avoided } \\
\text { Coal Use } \\
\text { (metric tons) }\end{array}$ & $\begin{array}{c}\text { Avoided } \\
\text { Coal Use } \\
\text { (railcars) }\end{array}$ \\
\hline $\begin{array}{c}\text { P4 Reburn } \\
\text { Total since } \\
2000\end{array}$ & $\begin{array}{c}1,078,555 \\
(978,449)\end{array}$ & $\begin{array}{c}583,334 \\
(529,192)\end{array}$ & $\begin{array}{c}657,137 \\
(596,145)\end{array}$ & $\begin{array}{c}335,138 \\
(304,032)\end{array}$ & 2,921 \\
\hline $\begin{array}{c}\text { PIPP Reburn } \\
\text { Total since } \\
\text { 2002 }\end{array}$ & 38,226 & 11,321 & 13,213 & 9,585 & 83 \\
\hline $\begin{array}{c}\text { ERGS Reburn } \\
\text { Total since } \\
2011\end{array}$ & $(34,678)$ & $(10,270)$ & $(11,987)$ & $(8,695)$ & \\
\hline
\end{tabular}

The ash recovery process can also be used to remove coal ash from company landfills for use as an alternative to sand/gravel and crushed stone material. The process involves excavating topsoil, clay or synthetic liners, fill and rooting zone cover materials, so that the coal combustion products can be processed. Upon removal completion, the land is restored in accordance with all applicable regulations. The recovered ash is crushed and screened to remove chunks and foreign materials according to the specifications of the end user as shown on Table 4. Annual quantities of recovered ash are based on market demand. The entire Pleasant Prairie ash landfill was recovered, removed and replaced with a modern state-of-the-art new ash landfill facility that now serves primarily as a contingency for the plant.

Other We Energies fly ash beneficiation process. We Energies patented an ammonia removal process for fly ash (U.S. Patent 6,945,179 and Canadian Patent 2,346,478) that can be used to overcome the effects of the $\mathrm{NO}_{\mathrm{x}}$ reduction technologies that use ammonia by liberating ammonia compounds from fly 
ash with heat applied in a high temperature air slide. The process makes it possible to control $\mathrm{NO}_{\mathrm{x}}$ emissions, market ash as a commercial product, and recycle the liberated ammonia compounds [Ramme, Fischer, Naik 2001].

We Energies developed processes (U.S. Patent 7,217,401) for removing mercury compounds from fly ash and spent activated carbon sorbents through a thermal process in a high temperature air slide. The process has been demonstrated on a pilot scale and makes it possible to remove the captured mercury for commercial reuse or sequestration, and allows the activated carbon sorbents to be recycled in a continuous process [Li, Gao, Goeckner, Kollakowsky, Ramme 2005] [Okwadha, Li, Ramme, Kollakowsky, Michaud 2009].

Table 4. Sieve Analysis of Pleasant Prairie Ash Landfill Recovered Coal Ash

\begin{tabular}{|c|l|c|c|r|}
\hline \multicolumn{2}{|c|}{ Sieve Size } & \multirow{2}{*}{$\begin{array}{c}\text { Weight } \\
\text { Percentage }\end{array}$} & $\begin{array}{c}\text { Percent } \\
\text { Retained }\end{array}$ & $\begin{array}{c}\text { Percent } \\
\text { Passing }\end{array}$ \\
\hline Metric(mm) & \multicolumn{1}{|c|}{ UStd } & 0.00 & 0.00 & 100.00 \\
\hline 50.8 & $2^{\prime \prime}$ & 0.00 & 0.00 & 100.00 \\
\hline 38.1 & $1.5^{\prime \prime}$ & 2.25 & 2.25 & 97.75 \\
\hline 25.4 & $1^{\prime \prime}$ & 2.52 & 4.77 & 95.23 \\
\hline 19.05 & $0.75^{\prime \prime}$ & 5.82 & 10.59 & 89.41 \\
\hline 12.7 & $0.5^{\prime \prime}$ & 13.56 & 24.15 & 75.85 \\
\hline 9.525 & $0.375 "$ & 14.16 & 38.31 & 61.69 \\
\hline 2.36 & $\# 8$ & 10.44 & 48.75 & 51.25 \\
\hline 1.18 & $\# 16$ & 12.00 & 60.75 & 39.25 \\
\hline 0.6 & $\# 30$ & 11.97 & 72.72 & 27.28 \\
\hline 0.3 & $\# 50$ & 16.85 & 89.57 & 10.43 \\
\hline 0.15 & $\# 100$ & 7.54 & 97.11 & 2.89 \\
\hline 0.075 & $\# 200$ & 1.86 & 98.97 & 1.03 \\
\hline 0.045 & $\# 325$ & & & \\
\hline
\end{tabular}

\section{GYPSUM}

As part of We Energies environmental commitment to reduce emissions and develop higher value uses for its combustion products, flue gas desulfurization (FGD) systems that produce a high purity (> 95\%) gypsum product were selected for the Elm Road Generating Station, Oak Creek Power Plant, and Pleasant Prairie Power Plant. Nearly all of the gypsum, chemically known as calcium sulfate di-hydrate $\left(\mathrm{CaSO}_{4}-2 \mathrm{H}_{2} \mathrm{O}\right)$ produced by We Energies through 2015 has been utilized in wallboard manufacturing and agriculture. Interest in the product has also been expressed for use in Portland cement manufacturing. FGD gypsum is a sustainable alternative to mined gypsum with advantages of high purity, local production, and a fine particle size. The fine particle size saves the milling step in wallboard manufacturing, and facilitates the rapid release of calcium and sulfur to plants in agriculture. Table 5 shows a typical chemical and physical analysis of the FGD gypsum produced at the Pleasant Prairie Power Plant.

The high purity, low moisture, and local availability of gypsum is valued by customers. Since the start-up of the first scrubber at Pleasant Prairie in late 2007, all (>99.6\%) of the approximately 1.50 million metric tons (1.65 million tons) of gypsum produced by We Energies has been utilized as either a raw material to produce drywall or a soil amendment for agricultural applications. In this manner, our gypsum reduces the overall demand and need for mined gypsum, which in turn reduces the impacts and energy consumption of the associated mining activities. The growth of agricultural gypsum has indeed been impressive, with over 463,000 metric tons (510,000 tons) of We Energies gypsum distributed to farms throughout Wisconsin, Illinois and Indiana since the program started in 2008. Gypsum improves soil conditions including permeability and moisture retention, which allows for deeper plant root penetration and increased access to nutrients in the soil. Gypsum is typically applied at rates of one-half to two tons per acre on several different 
crops including alfalfa, hay, corn, potatoes and ginseng. Research on the benefits of gypsum for agricultural use continues, and future studies will highlight the reduction in water run-off that results from the improved soil conditions. (http://www.we-energies.com/environmental/gypsum.htm)

Table 5. Gypsum Composition and Physical Properties

\begin{tabular}{|l|c|}
\hline Purity (dry basis) & Average \\
\hline $\left.\mathrm{Gypsum}_{(\mathrm{CaSO}} \bullet 2 \mathrm{H}_{2} \mathrm{O}\right)$ & $97.8 \%$ \\
\hline $\mathrm{CaCO}_{3}$ & $1.0 \%$ \\
\hline $\mathrm{MgCO}_{3}$ & $0.5 \%$ \\
\hline$(\mathrm{Al} \text { and } \mathrm{Fe})_{2} \mathrm{O}_{3}$ & $0.1 \%$ \\
\hline Bulk Density (as produced) & $70 \mathrm{lb} / \mathrm{cu} . \mathrm{ft}$. \\
\hline Moisture (as produced) & $\leq 10 \%$ \\
\hline Specific Gravity & 2.38 \\
\hline
\end{tabular}

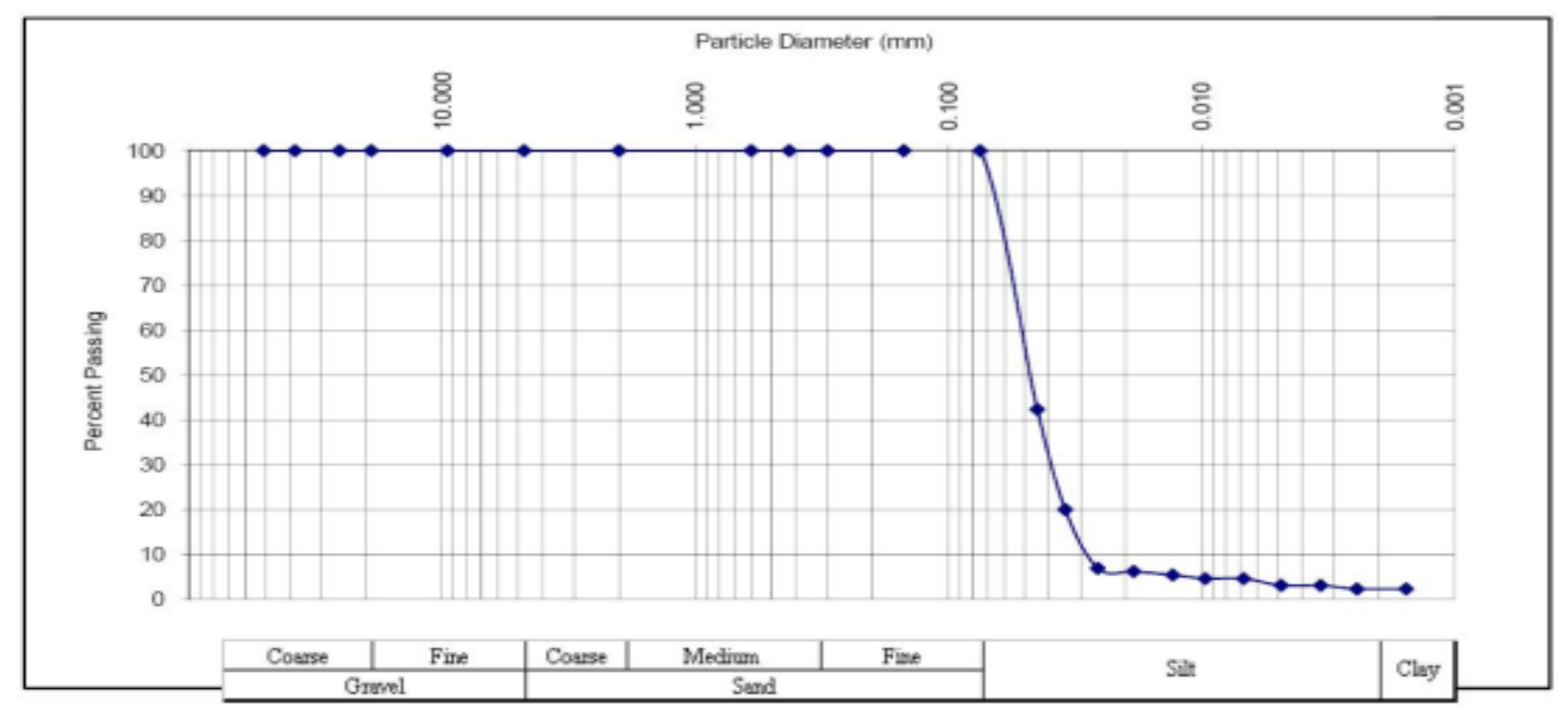

Figure 4. Pleasant Prairie Gypsum Particle Size Distribution

Another highlight for gypsum utilization is the continued demand for our high quality gypsum by drywall manufacturing companies. Since our first wet scrubber came on line in 2007, thru 2014 we have supplied more than 1 million tons ( 0.9 million metric tons) of gypsum to drywall manufacturing companies.

\section{WOOD ASH}

In November 2013, We Energies began producing wood ash at the Rothschild Biomass Cogeneration Plant with circulating fluidized bed combustion technology. Both fly and bottom ash products are produced. From the beginning of commercial operation, the bottom ash has been used for construction applications replacing crushed stone, sand and gravel. Utilization of the fly ash from woody biomass followed within six months of commercial operation. The fly ash is less cementitious than coal fly ash, contains higher levels plant nutrients (phosphorus, potassium), and is higher in alkalinity. These properties lend themselves to use as an agricultural lime substitute (reduce the acidity of soil) or as a fertilizer. 


\section{OTHER APPLICATIONS}

Ash Alloy. (U.S. Patent No. 5,711,362 and No. 5,897,943): We Energies holds two U.S. patents that relate to the use of fly ash in producing metal matrix composites, such as aluminum castings. The patents are the result of research work conducted with area foundries, the Electric Power Research Institute and the University of Wisconsin in Milwaukee. Prototype automotive parts such as manifolds and brake drums have been produced for testing purposes. The addition of fly ash to produce composite metals can alter the density, weight, hardness, crack propensity, and mechanical properties of selected parts. Composite material technology holds promise for lower cost alloys and an even higher value uses for fly ash [Rohatgi1996] [Birdsall 1996].

Electrically Conductive Concrete and Controlled Low-Strength Materials. The Company holds U.S. patents $6,461,424,6,821,336$ and 7,578,881 for controlled low-strength material and concrete material that is less electrically resistant by adding fly ash or spent activated carbon sorbent that contains a high-carbon content. Like Thomas Edison's early filaments for the light bulb, the conductive properties of carbon in fly ash and spent activated carbon sorbents can provide the electrical pathways for numerous applications. These materials have promising implications for various utility and construction applications such as improved electrical grounding, lightning protection, transportation system sensors, and ice prevention on bridges, sidewalks, and airport runways [Ramme 2002].

Fly Ash Cenospheres - Dry Separation. We Energies has developed and patented processes (U.S. $8,074,804$ and $8,520,210$ ) for the dry separation of cenospheres from fly ash that involve sieving and/or classifying particles by size and density.

Mineral Enriched Water (Ash Landfill Leachate). We Energies has also developed and patented beneficial uses for ash mono-fill landfill leachates where dissolved ash constituents (such as calcium and sulfate) can be utilized in unreinforced concrete production to increase strength and also alter the time-ofset (U.S. 8,236,098).

Aggregates from $\mathrm{CO}_{2}$ Mineralization Processes. We Energies has developed and patented a $\mathrm{CO}_{2}$ mineralization process (U.S. 7,390,444 and 9,028,607) that utilizes lime rich by-products such as fly ash, slag, lime kiln dust, and cement kiln dust to capture carbon dioxide in foamed controlled low strength materials of targeted densities that can then be crushed and screened into alternative aggregates of desired gradations [Ramme, Goeckner, Russert, 2008] [Ramme, 2008].

"Eco-Pad" In-Situ Mixed Concrete Pavement. A concrete construction process has been developed that utilizes up to $100 \%$ recycled or by-product materials for pavements with up to a $12 \mathrm{in}$. $(30 \mathrm{~cm})$ thickness. Crushed recycled concrete is used as an alternative for coarse aggregate, and bottom ash as an alternative to sand. A 50/50 blend of Class C fly ash and ground granulated blast furnace slag were used as the cementitious materials for one half of the pavement and a 50/50 blend of portland cement and Class C fly ash is used for the other half. The aggregates are tailgated and spread in specified layers on the subgrade. A single pass with an asphalt reclaimer is used to pre-blend the aggregates and water is added to target optimum moisture conditions for compaction. A vane feeder is used to apply the cementitious powdered materials, and water is added to target optimum compaction moisture conditions. An asphalt reclaimer is used for mixing the concrete ingredients in place followed immediately by vibratory rollers. The process essentially uses asphalt construction equipment and the concrete surface texture is similar to finished asphalt. Saw cutting can be used to avoid random shrinkage crack patterns in the same fashion as conventional concrete. 3000 psi (21 Mpa) compressive strengths have been achieved with these materials and construction process using a 50/50 blend of Class $\mathrm{C}$ fly ash and ground granulated blast furnace slag as the binder. Higher early strengths can be obtained substituting Portland cement for the slag or fly ash if needed. Laboratory trial testing with the specific available materials is essential component to having success in construction [Ramme, Jansen, Ravil, Anderson 2007]. 


\section{SUMMARY OF SUSTAINABLE BENEFITS}

There are several environmental, economic and social benefits to utilizing coal combustion products at We Energies. For example the ash fuel reburn process environmental benefits include preserving existing landfill capacity, reducing the need for new landfills and conserving natural resources. Natural resources include coal, clay, limestone, shale, crushed stone, sand and gravel that are preserved when coal combustion products are utilized as a supplemental fuel, cement raw feed material or in aggregate production. Since most of the fly ash produced by the reburn systems is used to replace portland cement in concrete, the program also offsets carbon dioxide $\left(\mathrm{CO}_{2}\right)$, nitrogen oxides $\left(\mathrm{NO}_{\mathrm{x}}\right)$, hydrogen chloride $(\mathrm{HCl})$, and sulfur oxides $\left(\mathrm{SO}_{\mathrm{x}}\right.$ ) emissions that normally occur in the production of additional portland cement. Judicious additions of high-carbon coal ash as a supplemental fuel can improve the resulting fly ash chemistry and quality for better concrete durability, strength, and workability.

Economic advantages of CCP utilization can result in turning an expense into a new revenue stream. For example, the reburn economic advantages include avoided coal purchases, avoided landfill expenses, and additional revenue from producing and selling concrete quality fly ash and bottom ash. Additional benefits include the ability to recover energy that would otherwise be lost and to conserve resources for use by future generations. When ash is recovered from landfills and reburned or used as alternative aggregate, former landfill acreage can be redeveloped. In the case of legacy remediation projects, the ash fuel reburn process offers an economical and effective alternative to conventional removal and landfill approaches. Our customers benefit by having locally produced quality construction materials and a reduced cost for energy production.

Innovative applications promise further economic savings and new tools for providing cost effective services for our customers and the construction industry. This research engages many university students and researchers that later go into private industry. Industry benefits and taps into this pool of talent that is educated about the benefits and potential uses of CCP.

Globally, we see an emphasis on green construction, sustainable development and preserving natural resources for use by future generations. When we utilize a natural resource such as coal for a portion of our generation needs, we can help preserve other natural resources (clay, sand, gravel, crushed stone, shale and limestone) by fully utilizing the remaining coal combustion products that come along with the fuel. Architects sometimes specify a percent recycled content for new structures and site development projects. Coal combustion products are available to help fulfill these "green" and sustainable development requirements [Malhotra 1999] [Mehta 2002] [Naik 2002] [Holland 2002].

We Energies recognizes the need to demonstrate leadership in the use of coal combustion products for all construction applications. Utilities need to be out front in advocating CCP utilization with good environmental stewardship on their own projects to serve as a model for the entire construction industry. We Energies shares CCP utilization experience locally, nationally and globally with presentations, technical papers and in our coal combustion products handbook which is frequently referenced and available at: https://www.we-energies.com/environmental/ccp_handbook.pdf [Ramme, Tharaniyil 2013].

\section{CONCLUSION}

The landfill option for coal combustion products is rapidly becoming a part of We Energies history. Landfilling has become increasingly less desirable due to higher landfill development and ash disposal costs, greater difficulty in siting landfills and the associated potential long-term environmental liabilities. The commitment to establish a coal combustion product utilization program is only the first step. Borrowing from the successes of other utilization programs may provide only limited benefits due to: 
- Significant differences in coal combustion product characteristics between power plants.

- The proximity of coal combustion product sources to potential markets and associated transportation costs.

- Cost and local availability of virgin construction materials (a significant impact on the potential for utilization).

- The strong desire of local design engineers, regulators and contractors to require test and demonstration results using site specific coal combustion products before permitting and/or specifying their use.

Through the efforts of combustion product marketing, company research, and work by others; utilization of We Energies coal combustion products has increased from 5\% to approximately $102 \%$ system-wide between 1980 and 2014. Our goal is to continuously exceed $100 \%$ utilization and continue to reclaim the ash stored in our monofill landfills.

\section{REFERENCES}

American Coal Ash Association (2015), "Coal Combustion Product (CCP) Production and Use Survey Results”, https://www.acaa-usa.org/Publications/Production-Use-Reports

Bautista, E. G., Flickinger, J., Saha, R., Flores-Vivian, I., Faheem, A. F., and Sobolev, K.; "Journal of Construction and Building Materials," Vol. 94, pp 572-578.

Birdsall, E. (1996), "Advanced Automobile Materials - Aluminum and Magnesium Metal Matrix Composites Enhanced With Fly Ash.", Syn Ex Inc.

Byers, H. W. (1987), "Fludge: The Best of "Both Worlds," presented at the meeting of the Illinois Water Pollution Control Association and the Central States Water Pollution Control Association, Chicago, Illinois.

Collins, W. (1985), "Pozzo-Crete," Proceedings of the Seventh International Ash Utilization Symposium and Exposition, Orlando, Florida.

Covi, A. (2013), "ASHphalt Paving: Better Performance Using Fly Ash - Amended Binders in Asphaltic Concrete," Ash at Work, Issue 1, American Coal Ash Association, pp 22-25.

Crovetti, J. (1998), Marquette University, Center for Highway and Traffic Engineering,

"Design, Construction and Performance of Fly Ash Stabilized CIR Asphalt Pavements in Wisconsin", Prepared for Wisconsin Electric Power Company.

Holland, T. C. (2002), "Sustainability of the Concrete Industry - What Should Be ACI's Role?, "Concrete International, pp 35-40.

Li, J., Gao, X., Goeckner, B., Kollakowsky, D., and Ramme, B. W. (2005), “A Pilot Study of Mercury Liberation and Capture from Coal-Fired Power Plant Fly Ash," Journal of the Air \& Waste Management Association, Vol. 55, pp 258-264.

Malhotra, V. M. (1999), "Making Concrete Greener With Fly Ash," Concrete International, V. 21, No. 5, pp 61-66.

Malisch. W. R. (1998), “Blending Fly Ash for a Better Concrete.” The Concrete Producer.

Mehta, P. K. (2002), "Greening of the Concrete Industry for Sustainable Development," Concrete International, pp 23-28.

Meidl, R. J. (2015), “NR538 Reporting: Use of We Energies Coal Combustion Products - Year 2014”, 
Report submitted to the Wisconsin Department of Natural Resources.

Naik, T. R. (2002), “Greener Concrete Using Recycled Materials,” Concrete International, pp 45-49.

Naik, T. R. and Ramme, B. W. (1987), "Low Cement Content High Strength Concrete," Cement and Concrete Research, Vol 17, pp 283-294.

Naik, T. R., and Ramme, B. W. (1990), "High Early Strength Concrete Containing Large Quantities of Fly Ash, "Proceedings of the ASCE Materials Congress, Denver, Colorado.

Naik, T. R., Sohns, L. E. and Ramme, B. W. (1991), "High Strength Fly Ash Concrete for Prestressed Concrete Products," Precast/Prestressed Concrete Institute Journal, Vol 35, pp 72-78.

Naik, T. R., Ramme, B. W. and Kolbeck, H. J. (1990), "Use of CLSM Fly Ash Slurry for Filling Abandoned Underground Facilities," Concrete International, Vol 12, pp 19-25.

Naik, T. R., Ramme, B. W. and Kolbeck, H. J. (1991), "Controlled Low Strength Material (CLSM) Produced with High-Lime Fly Ash," Proceedings: Shanghai 1991 Ash Utilization Conference, Electric Power Research Institute, Palo Alto, California, Project 2422, GS-7388, Vol 3, pp 110-1 through 110-11.

Naik, T. R. and Ramme, B. W. (1994), "Low Strength Concrete and Controlled Low Strength Material (CLSM) Produced with Class F Fly Ash," presented at the 1992 ACI Spring Convention held in Washington, D.C., March 14-20, 1992 and also published in ACI Special Publication 150, Controlled Low Strength Materials, pp 1-14.

Naik, T. R., Sivasundaram, V. and Singh, S. S. (1991), "Use of High Volume Class F Fly Ash for Structural Grade Concrete," presented at the 70th Annual Conference of the Transportation Research Board, Washington, D.C.

Naik, T. R., Ramme, B. W., and Tews, J. H. (1994), "Use of High Volumes of Class C and Class F Fly Ash in Concrete, Cement, Concrete and Aggregates, ASTM, Vol. 16, No. 1, pp 12-20.

Naik, T. R. and Ramme, B. W. (1997), "Roller Compacted No-Fines Concrete Containing Fly Ash for Road Base Course," presented at the 1997 Third CANMET/ACI International Symposium on Advances in Concrete Technology in Auckland, New Zealand, pp 201-220 of Supplementary Papers.

Naik, T. R., Singh, S. S., and Ramme, B. W. (1997), "Mechanical and Durability Properties of Concrete Made with Blended Ash," Center for By-Products Utilization, CBU-1996-05 REP268, presented at $4^{\text {th }}$ CANMET/ACI International Conference on Durability of Concrete, Sydney, Australia.

Okwadha, G. D. O., Li, J., Ramme, B. W., Kollakowsky, D., and Michaud, D. (2009), "Thermal Removal of Mercury in Spent Powdered Activated Carbon (PAC) from Toxecon Process," ASCE Journal of Environmental Engineering.

Peterson, A. E., Schulte, E. E., and Speth, P. E. (1989), "Crop and Soil Responses to Land Application of Bottom Ash," A University of Wisconsin, Department of Soil Science final report to Wisconsin Electric Power Company, $51 \mathrm{p}$.

Ramme, B. W., Naik, T. R., and Kolbeck, H. J. (1995), "Construction Experience with CLSM Fly Ash Slurry for Underground Facilities," American Concrete Institute, Special Publication 53, pp 403-416.

Ramme, B. W., Kohl. T. A., and Oakes, D. (1999); "Use of Wisconsin Electric Bottom Ash Sand and Gravel as Sub-Base and Base Material for Rigid and Flexible Pavements and Floors", Presented at the 1999 ASCE Materials Engineering Division: MATCong5 - The $5^{\text {th }}$ Materials Engineering Congress in Cincinnati, Ohio. 
Ramme B. W. (2003), “Coal Combustion Products Recovery Process”, U.S. Patent No. 6,637,354B2, We Energies.

Ramme B. W. (1999), "Reburning of Coal Ash”, U.S. Patent No. 5,992,336, We Energies.

Ramme, B. W., and Goeckner, B. (2003), "Ash Fuel Reburn and Beneficiation at We Energies," presented at the Conference on Unburned Carbon on Utility Flyash, Pittsburgh, PA, available at http://www.netl.doe.gov/

Ramme, B. W., Fischer, B. C., and Naik, T. R. (2001), "Three New Ash Beneficiation Processes for the $21^{\text {st }}$ Century." Seventh CANMET/ACI International Conference Fly Ash, Silica Fume, Slag and Natural Pozzolans in Concrete, Volume 1. p. 325-338.

Ramme B. W. et al (2002), "Electrically Conductive Concrete and Controlled Low-strength Materials", U.S. Patent No. 6,461,424B1, We Energies.

Ramme, B. W., Goeckner, B. D., and Russert, J. J. (2008), "Carbon Dioxide Sequestration in Foamed Controlled Low Strength Materials," U.S. Patent No. 7390, 444B2, We Energies.

Ramme, B. W. (2008), "An Investigation of $\mathrm{CO}_{2}$ Sequestration through Mineralization," Ph.D. Dissertation, University of Wisconsin-Milwaukee, 304 pages.

Ramme, B. W., Jansen, T., Ravil, A., and Anderson, D. B. (2007), "Eco-Pad In-Situ Mixed Concrete with a 93-100\% Total Recycled Content, Proceedings of the Coventry University and the University of Wisconsin-Milwaukee Center for By-Products Utilization First International Conference on Sustainable Construction Materials and Technologies, held at Coventry University, UK.

Ramme, B. W., and Tharaniyil, M. P. (2013), "We Energies Combustion Products Utilization Handbook," Third Edition available at

https://www.we-energies.com/environmental/ccp_handbook.pdf

Rohatgi, P. K. (1996), "Casting of ASHALLOY Metal Matrix Composites: 1993", EPRI TR-105822, 9047-01, Interim Report.

Rohatgi, P. K. (1996), "Casting of ASHALlOY Metal Matrix Composites: 1994", EPRI TR106168, 9047-01, Interim Report.

Sivasundaram, V., Carette G. G., and Malhotra V. M. (1989), "Properties of Concrete Incorporating Low Quantity of Cement and High Volumes of Low-Calcium Fly Ash," Proceedings of the Third International Conference on Fly Ash, Silica Fume, Slag and Natural Pozzolans in Concrete, Trondheim, Norway.

Tews, J. H. (1995) "HVFA Concrete and TIF Districts, a Good Partnership!" presented at the American Concrete Pavement Association Annual Meeting, November 28 to December 2 in Marco Island, Florida.

Wen H., Tharaniyil M., Ramme B.W., and Krebs S. (2004), "Field Performance Evaluation of Type C Fly Ash in Full-depth Reclamation: A Case History Study", accepted for Publication at Journal of Transportation Research Board, Washington D.C.

Wen H., Tharaniyil M., and Ramme B.W. (2003), "Investigation of Performance of Asphalt Pavement with Fly Ash Stabilized Cold In-Place Recycled Base Course." Transportation Research Record, No 1819, Vol. 2, Transportation Research Bd., National Research Council, Washington D.C., pp.27-31. 